\title{
Back to Paris
}

\author{
Axel Munthe
}

I had been away three months instead of one. I felt sure that many of my patients would stick to my friend Doctor Norstrom, who had been looking after them during my absence. I was mistaken, they all came back to me, some better, some worse, all speaking very kindly of my colleague but equally kindly of me. I should not have minded in the least if they had stuck to him, I had my hands full in any case and I knew that his practice was dwindling away more and more, that he had even had to move from Boulevard Haussmann to a more modest apartment in Rue Pigalle. Norstrom had always been a loyal friend, had helped me out of many scrapes in the beginning of my career when I was still dabbling in surgery, always ready to share the responsibility for my many blunders. I well remember, for instance, the case of Baron B. I think I had better tell you this story to make you understand what sort of man my friend was. Baron B., one of the oldest members of the Swedish colony, always in indifferent health, had been attended by Norstrom for years. One day Norstrom with his fatal timidity suggested that I should be called in consultation.

The Baron took a great liking to me. A new doctor is always believed to be a good doctor until he has been proved the contrary. Norstrom wanted an immediate operation, I was against it. The Baron wrote to me he was getting tired of Norstrom's gloomy face and asked me to take him in hand. Of course I refused, but Norstrom insisted upon retiring and my taking over the case. The Baron's general condition improved rapidly, I was congratulated on all sides. A month later it became clear to me that Norstrom was right in his diagnosis, but that it was now too late for an operation, that the man was doomed. I wrote to his nephew in Stockholm to come out to bring him home to die in his own country. It was with the greatest difficulty I succeeded in persuading the old gentleman. He did not want to leave me; I was the only doctor who understood his case. A couple of months later his nephew wrote to me that his uncle had left me in his will a very valuable gold repeater in remembrance of what I had done for him,

I often make it strike the hour to remind me what sort of stuff the reputation of a doctor is made of. Of late the position between Norstrom and me had somewhat changed. I was more and more called in consultation by his patients, much too often. I had just seen one of them die rather unexpectedly that very afternoon, the worse luck for Norstrom as the patient was one of the best known members of the colony. Norstrom was very much upset about it. I took him to dine with me at Cafe de la Regence to cheer him up a little. "I wish you

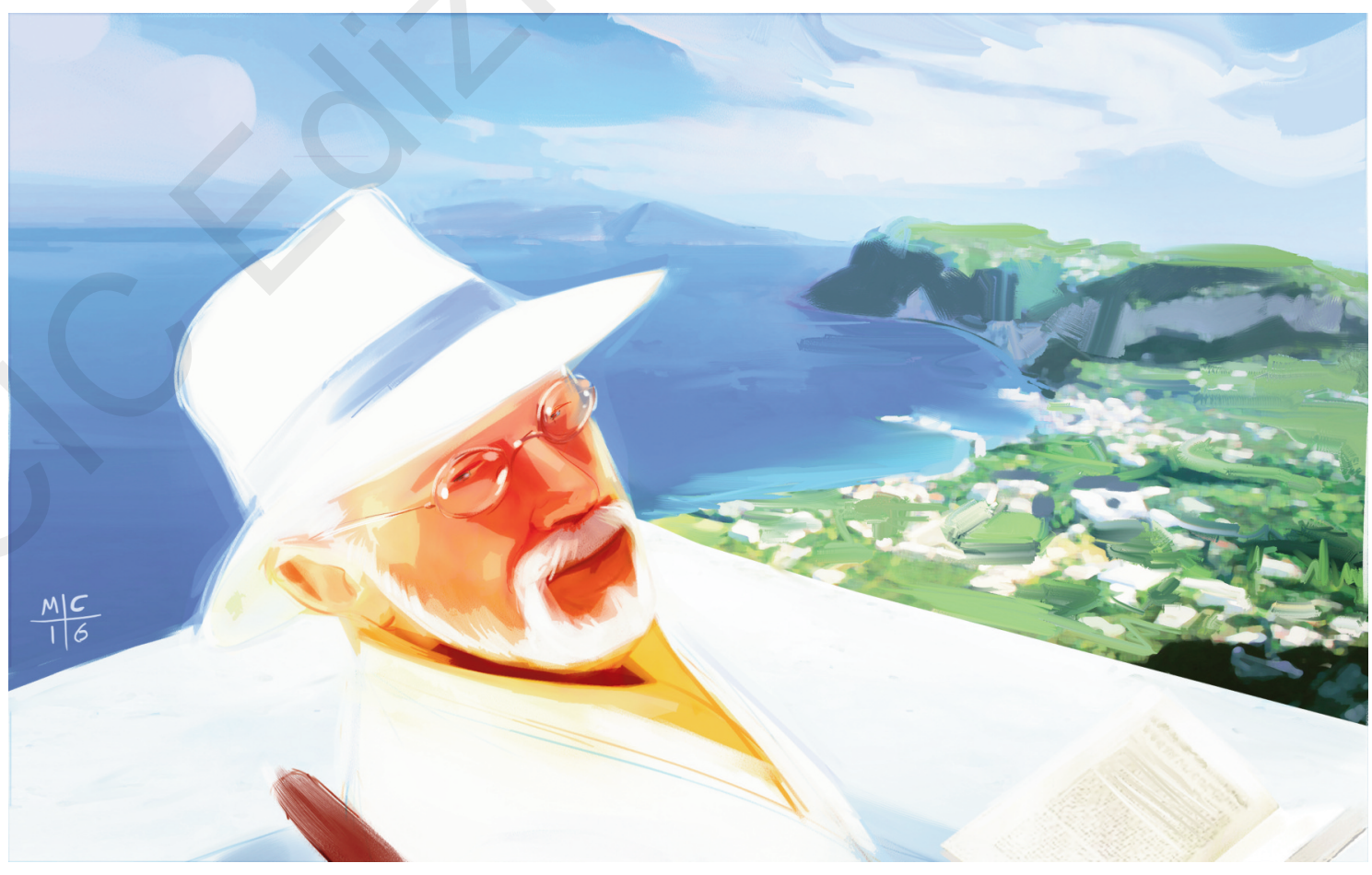


could explain to me the secret of your success and of my failure," said Norstrom looking gloomily at me across the bottle of St. Julien. "It is above all a question of luck," said I. "There is also a temperamental difference between you and me which enables me to seize Fortune by her hair while you sit still and let her fly past, your hands in your pockets. I am convinced that you know more than I do about the human body in health and disease; it is just possible that although you are twice my age, I know more than you do about the human mind. Why did you tell the Russian professor I handed over to you that he had angina pectoris, why did you explain to him all the symptoms of his fatal disease?"

"He insisted upon knowing the truth, I had to tell him or he would not have obeyed me".

"I did not tell him anything of the sort, he obeyed me anyhow. He told you a lie when he told you he wanted to know everything and that he was not afraid of death. Nobody wants to know how ill he is, everybody is afraid of death and for good reason. This man now is far worse. His existence is paralysed by fear, it is all your fault". "You are always talking about nerves and mind as if our body was made of nothing else. The cause of angina pectoris is arteriosclerosis of the coronary arteries". "Ask Professor Huchard what happened in his clinic last week while he was demonstrating to us a case of angina pectoris! The woman suddenly started a terrible attack which the Professor himself thought would be fatal. I asked his permission to try to stop it with mental treatment, he said it was useless but he consented. I laid my hand on her forehead, and told her it would pass off immediately, a minute later the terror went out of her eyes, she drew a deep breath and said she felt all right. Of course you say it was a ease of pseudo-angina; I can prove you the contrary. Four days later she had another to all appearance quite similar attack, she died in less than five minutes. You are always trying to explain to your patients what you cannot even explain to yourself. [.....]".

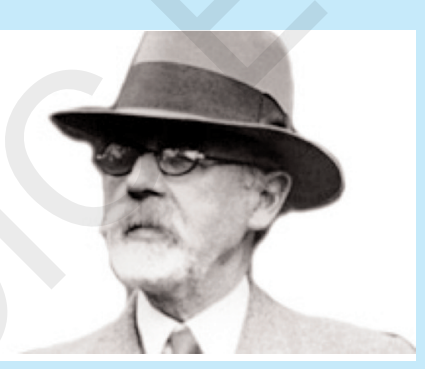
in a cholera epidemic. In 1887, he moved to Capri, bought the Villa San Michele, now house of the Sweden Consul in Italy, and began restoration, doing much of the work himself. Axel Munthe served as personal physician of the Swedish Queen Victoria who suffered from severe bronchitis and tuberculosis. The Queen spend her winters on Capri for her health sharing Munthe's love of animals, and helped support his efforts to purchase Mount Barbarossa to establish it as a bird sanctuary. The "Story of San Michele" was a best-seller in numerous languages constantly republished since its original release, so overshadowing all Munthe's other publications, such as "Letters From A Mourning City", "Vagaries", "Red Cross and Iron Cross by a doctor in France". 